Economics Development Analysis Journal 5(4)(2016)

\title{
Strategi Pemberdayaan Ekonomi Petani Garam Melalui Pendayagunaan Aset Tanah Pegaraman
}

\author{
Ihsannudin ${ }^{1 凶}$, Sukmo Pinujib ${ }^{2}$, Subejo ${ }^{3}$, Bertus Sumada Bangko ${ }^{4}$
}

${ }^{1}$ Prodi Agribisnis, Fakultas Pertanian, Universitas Trunojoyo Madura, ${ }^{2}$ Sekolah Tinggi Pertanahan Nasional Yogyakarta, ${ }^{3}$ Prodi Penyuluhan dan Komunikasi Pertanian, Fakultas Pertanian, Universitas Gadjah Mada, ${ }^{4}$ Puslitbang Kementerian Agraria dan Tata Ruang/ Badan Pertanahan Nasional

\begin{tabular}{|c|c|}
\hline Info Artikel & Abstrak \\
\hline $\begin{array}{l}\text { Sejarah Artikel: } \\
\text { Diterima September } \\
2016 \\
\text { Disetujui Oktober } 2016 \\
\text { Dipublikasikan } \\
\text { November } 2016\end{array}$ & $\begin{array}{l}\text { Madura bernilai strategis dalam produksi garam nasional, namun kenyataannya kondisi petani garam masih } \\
\text { hidup di bawah garis kemiskinan. Penelitian bertujuan merumuskan strategi pemberdayaan petani garam melalui } \\
\text { pendayagunaan aset pertanahan dengan pendekatan subsistem budaya-kelembagaan dan subsistem ekonomi. } \\
\text { Guna mencapai hal tersebut, perlu diketahui kondisi subsistem budaya-kelembagaan dan subsistem ekonomi } \\
\text { petani garam. Selain itu, dikaji faktor-faktor penyebab ketidakberdayaan petani. Hasil analisis menunjukkan } \\
\text { subsistem budaya menunjukkan bahwa usaha pegaraman adalah bagian budaya masyarakat yang mengakar dan } \\
\text { tidak dapat dipisahkan dari masyarakat Madura. Sementara dari subsistem kelembagaan menunjukkan petani } \\
\text { garam dikelompokkan menjadi petani pemilik tanah dan petani penggarap (mantong). Pendekatan subsistem } \\
\text { ekonomi menunjukkan bahwa produksi garam sangat tergantung iklim dan cuaca dan masih menggunakan } \\
\text { teknologi tradisional. Strategi pemberdayaan bagi petani pemilik tanah adalah dengan mengupayakan sertifikasi } \\
\text { tanah untuk mendukung akses permodalan. Sementara untuk mantong diarahkan memperoleh redistribusi tanah } \\
\text { oyek landreform yang kemudian disertifikasi. Tanah tanah yang telah disertifikasi tersebut nantinya dapat } \\
\text { dilakukan konsolidasi tanah yang berperan pada peningkatan kuantitas dan kualitas produksi garam serta } \\
\text { mereduksi biaya transportasi. Tanah yang telah tersertifikasi juga dapat digunakan untuk agunan guna }\end{array}$ \\
\hline
\end{tabular}

\begin{abstract}
Madura has an important role in the national salt production. unfortunately, most of salt farmers in Madura are living under the poverty line. This paper discuss about the strategies to empower salt farmers through improving the access of lands, proposing culture-institutional and economic subsytem approch. This strategy can be formulated by investigate the condition of the cultural-institutional and economic subsystem of salt farmers. In addition, also discussed the factors that cause the incapacities of the farmers to improve their welfare. The result based on cultural subsystem show that salt production is part of the Madura culture that deeply entrenched. Then, based on institutional subsystem show salt farmers can be divided into two type: the farmers that own their lands and peasant farmers (mantong). Meanwhile, based on economic sub system describe the existing salt production system is traditionally managed, highly dependent on the weather and climate condition. An empowerment strategy for the landowners is to get land registration to access the capital. While empowering for mantong directed to acquire redistribution on land reform object. Salt land that has been certified can be consolidated which contribute to increasing the quantity and quality of salt production and reduce transportation costs. Then salt that has been certified can be be used for collateral in order to access capital.
\end{abstract}

(C) 2016 Universitas Negeri Semarang

\footnotetext{
Alamat korespondensi:

J1. Raya Telang, Telang, Kamal, Telang, Kamal, Madura, Jawa

Timur 69162

E-mail: ihsannudin.utm@gmail.com
} ISSN 2252-6765 


\section{PENDAHULUAN}

Komoditas garam, selain untuk memenuhi kebutuhan konsumsi juga digunakan untuk memenuhi kebutuhan industri. Tercatat kebutuhan garam nasional pada 2015 untuk konsumsi dan industri sebesar 3,8 juta ton yang terdiri atas 1,7 juta ton untuk keperluan konsumsi dan 2,1 juta ton untuk keperluan industri. Produksi garam nasional yang dilakukan oleh petani garam dan PT. Garam sebagai satu-satunya BUMN yang memproduksi garam hanya sebesar 2,1 juta ton. Pemenuhan kekurangan garam sebesar 1,7 juta ton dipenuhi dari impor (Kompas, 2015). Kondisi ini menunjukkan suatu ironi dimana Indonesia merupakan negara yang kaya akan potensi sumberdaya laut namun belum mampu memenuhi kebutuhan garam nasional. Hal itulah yang menyebabkan Indonesia mengimpor garam dengan nilai $\mathrm{Rp}$ lebih dari 1 triliun ( 90,000 USD) setiap tahunnya (Susanto, 2015).

Secara nasional, potensi lahan penggaraman seluas 34.731 ha namun pengusahaannya masih relatif terbatas yaitu sebesar $20.089 \mathrm{Ha}$ yang merupakan lahan penggaraman produktif. Sekitar $60 \%$ luas lahan penggaraman produktif berada di Pulau Madura yang terdiri atas Kabupaten Sampang, Pamekasan dan Sumenep. Total luas lahan garam di ketiga Kabupaten tersebut yang telah diusahakan mencapai $11.625 \mathrm{Ha}$ dari total potensi lahan garam seluas $16.421 \mathrm{Ha}$.

Sebagai pelaku utama produksi yang berkontribusi besar terhadap produksi garam nasional, ternyata kondisi penghidupan para petani garam secara umum masih jauh dari ukuran sejahtera. Keadaan petani garam sebagaimana kehidupan pada masyarakat pesisir umumnya menghadapi berbagai permasalahan yang menyebabkan kemiskinan. Pada umumnya mereka menggantungkan hidupnya dari pemanfaatan sumberdaya laut dan pantai yang membutuhkan investasi besar dan sangat bergantung musim (Widodo, 2011). Kondisi iklim dan cuaca yang seringkali tidak bersahabat, mekanisme harga dan pasar garam yang cenderung tidak berpihak kepada petani garam menjadikan petani garam menjadi tidak berdaya. Demikian pula mayoritas tingkat pendidikan penduduk yang rendah dan keterampilan berusaha yang sangat terbatas (Syafi'i, 2006). Lebih lanjut Rochwulaningsih (2007) menyatakan bahwa struktur penguasaan lahan garam akan menentukan accessibity petani garam pada surplus atas produksinya. Secara sosial ekonomi petani garam yang menguasai lahan luas relatif lebih maju/kaya dibandingkan dengan petani yang menguasai lahan sempit apalagi petani penggarap/buruh pada umumnya lebih terbelakang/miskin. Dengan demikian polarisasi penguasaan lahan garam oleh kapitalis secara signifikan ikut memberi kontribusi bagi marjinalisasi petani garam terutama petani kecil dan petani penggarap/buruh.

Kondisi dan karaktersitik petani garam juga digambarkan dari jumlah pelaku produksi garam rakyat di Madura yang terdiri dari petani pemilik dan petani penggarap atau mantong yang berjumlah lebih dari 4.000 orang. Sebagian besar kehidupan petani garam masih berada di bawah garis kemiskinan (Ihsannudin, 2012b). Karateristik lain yang kurang menguntungkan adalah kondisi tingkat pendidikan petani garam yang rendah dan keterampilan berusaha yang sangat masih terbatas.

Menghadapi kondisi tersebut perlu adanya pemberdayaan ekonomi yang dilakukan kepada petani garam. Pemberdayaan petani garam sebenarnya dapat dilakukan dengan membentuk kelompok-kelompok kecil secara musiman seperti yang dilakukan di Afrika Selatan (Antonites, 2016). Pada lingkup yang lebih rinci pemberdayaan ekonomi masyarakat dilakukan sebagai upaya mentransformasikan pertumbuhan ekonomi masyarakat yang rendah dan stagnan ke arah pertumbuhan ekonomi yang lebih tinggi. Upaya tersebut dapat dilakukan dengan konsep pemberdayaan ekonomi masyarakat dengan melalui pendekatan Hayami dan Godo (2005). Konsep ini menawarkan dialektika interaksi antara ekonomi dan variabel budaya - kelembagaan sebagaimana yang ditunjukkan gambar 1 .

Pada bagian bawah gambar menunjukkan sektor ekonomi sebagai sub sistem sosial. Sub 
sistem ini terdiri atas interaksi antara teknologi dan sumberdaya yang secara umum didefinisikan sebagai faktor produksi, termasuk di dalamnya adalah sumberdaya alam, tenaga kerja, dan modal. Teknologi adalah penentu nilai produksi dari sebuah produk yang diproduksi dari adanya kombinasi faktor-faktor produksi atau seringkali dinamakan fungsi produksi dalam bidang ekonomi. Jika pertumbuhan ekonomi diukur dengan peningkatan pendapatan per kapita produk (income), maka kemudian menjadi hal yang wajar jika kemudian peningkatan per kapita sumberdaya atau progress dalam teknologi didefinisikan sebagai peningkatan produk karena pemberian input sumberdaya. Produk di sini didefinisikan sebagai nilai ekonomi baru yang diberikan kepada masyarakat berupa input tenaga kerja, modal dalam sumberdaya alam dalam suatu periode yang kesemuanya dilakukan guna meningkatkan pendapatan masyarakat.

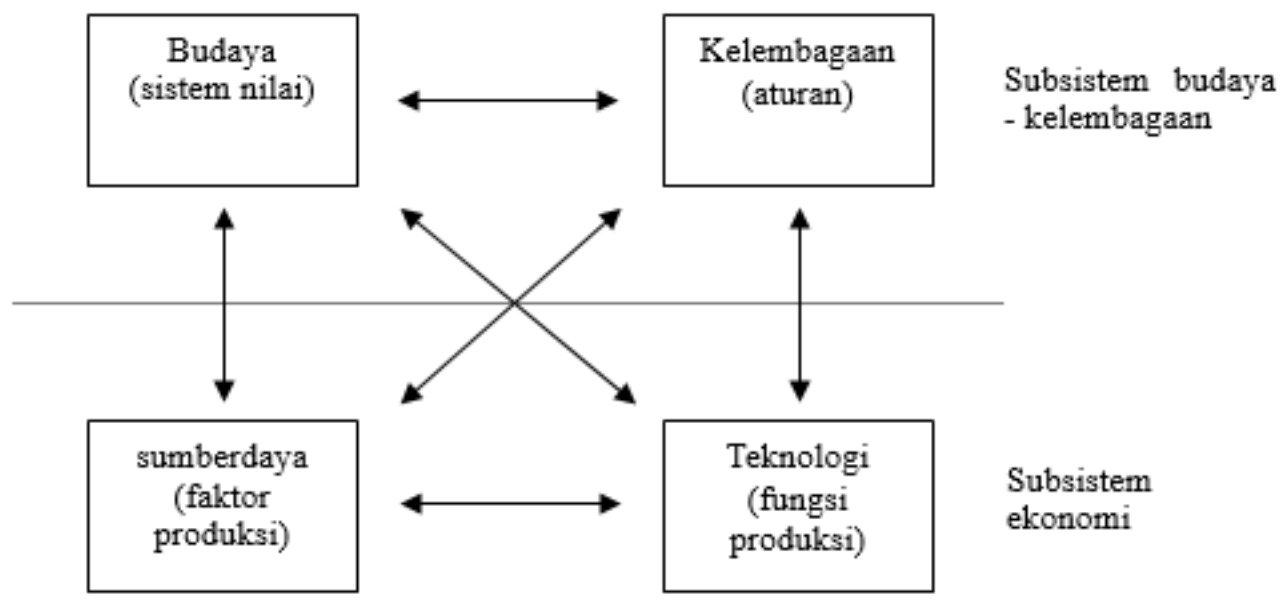

Gambar 1. Interelasi Pemberdayaan Masyarakat Dalam Sistem Sosial

(Sumber: Hayami dan Godo, 2005)

Pemberdayaan masyarakat perlu dilakukan dari segala aspek dan oleh segala lapisan untuk meningkatkan kapasitas yang ada di masyarakat guna meraih kesejahteraan. Konsep dalam pemberdayaan selalu dihubungkan dengan konsep mandiri, partisipasi dan jaringan kerja serta keadilan (Hikmat. 2010). Sehingga nantinya dalam pemberdayaan ini tidak bisa dilakukan hanya dengan mengandalkan konsep top down saja. Sinergi yang kuat antara pemerintah dan masyarakat, partisipasi masyarakat serta pemahaman yang komprehensif pada masyarakat yang akan diberdayakan adalah sebuah keharusan (Djamhuri, 2008; Xu, et al, 2010). Hal yang sama diungkapkan Scott (1998), bahwa pemerintah perlu menetapkan rencana-rencana rasional dengan pengaturan administrasi terhadap alam dan masyarakat sehingga rencana yang dibuat akan menjadi komprehensif dan tepat.

Salah satu aspek pemberdayaan yang dapat dilakukan adalah melalui pendayagunaan aset pertanahan. Tanah yang telah terigistrasi atau terpenuhi aspek legalitasnya terbukti memiliki nilai investasi yang tinggi yang dapat digunakan sebagai modal dan berpotensi besar dijadikan sebagai obyek pemberdayaan (Deininger dan Feder, 2009; Soto, 2006 dan Ihsannudin, 2012b). Pemberdayaan masyarakat terhadap aset pertanahan ini dilakukan agar petani garam mampu menjadikan tanah yang dimilikinya legal/ tersertipikasi dan menjadi active capital yang dapat dijaminkan untuk dijadikan tambahan modal dalam usahanya meningkatkan produksi dan kualitas garam melalui aplikasi teknologi baik secara fisik, kimia maupun biologi (Segal, dkk. 2009; 
Conghe, dkk. 2011; Ihsannudin, 2011). Hasil kajian serupa ditunjukkan oleh Byamugisha (1999), yang menyatakan bahwa terdapat keterkaitan yang signifikan antara status sertifikasi tanah dengan peningkatan akses kredit di pedesaan Thailand. Hasil perolehan kredit ini kemudian digunakan untuk pemupukan modal usaha pertanian yang lebih produktif.

Tanah pegaraman sebagaimana tanah lainnya sesuai dengan Undang-Undang Dasar 1945 Pasal 33 Ayat (3) memberikan landasan bahwa "bumi dan air dan kekayaan alam yang terkandung di dalamnya dikuasai oleh negara dan dipergunakan sebesar-besarnya untuk kemakmuran rakyat". Maka tanah, air serta kekayaan alam pada dasarnya dikuasai oleh negara. Dalam konteks ini, pemerintah telah mengeluarkan Undang-Undang Nomor 5 tahun 1960 Tentang Peraturan Dasar Pokok-Pokok Agraria, yang dimuat dalam Lembaran Negara Nomor 104 yang kemudian lazim dikenal dengan Undang-Undang Pokok Agraria atau disingkat dengan UUPA.

Beberapa pasal dalam Undang-Undang Nomor 5 Tahun 1960 ini, juga mengatur keharusan pemilik tanah untuk melakukan pendaftaran hak atas tanah miliknya (istilah di pertanahan adalah sertipikasi). Pendaftaran tersebut dimaksudkan untuk memperoleh kepastian hukum terhadap status tanah yang bersangkutan. Pasal pasal tersebut adalah Pasal 19, Pasal 23, Pasal 32 dan Pasal 38 UUPA. Peraturan lebih lanjut yang mengatur masalah pendaftaran tanah terdapat dalam Peraturan Pemerintah Nomor 24 Tahun 1997 tentang Pendaftaran Tanah dengan peraturan pelaksanaannya.

Kondisi faktual di lapangan menunjukkan masih cukup banyak bidang tanah termasuk tanah pegaraman yang dimiliki oleh petani garam belum bayak yang tersertipikasi (Windari, 2014). Penjelasan yang ebih spesifik sebagaimana hasil studi Ihsannudin, dkk (2015) menunjukkan bahwa hanya $2 \%$ saja yang telah mensertifikatkan tanah pegaramannya. Padahal, kepemilikan tanah ini memiliki arti yang demikian penting terhadap asset yang dimiliki untuk dapat dijadikan sebagai cash capital dalam usaha ekonomi produktif. Ada beberapa manfaat yang dapat diperoleh dengan adanya legalisasi asset ini (de Soto, 2006), di antaranya adalah; (1) optimalisasi secara ekonomi dari asset, (2) menyatukan informasi asset dalam sebuat system, (3) menjadikan pemilik asset bertanggungjawab, (4) asset menjadi lebih mudah diterima oleh pasar, (5) menjadikan pemiliki asset berada dalam suatu networking, (6) proteksi transaksi.

Mempertimbangkan problematikan pada uraian tersebut, studi yang dilakukan bertujuan untuk merumuskan strategi pemberdayaan ekonomi petani garam melalui pendayagunaan aset tanah pegaraman, yang dilakukan dengan (1) mengidentifikasi kondisi subsistem budayakelembagaan dan subsistem ekonomi petani garam, (2), menganalisis faktor faktor penyebab ketidakberdayaan petani garam (3) menyusun strategi pemberdayaan ekonomi petani garam melalui pendayagunaan aset tanah pegaraman.

\section{METODE PENELITIAN}

Penelitian dilaksanakan di 3 Kabupaten di Pulau Madura sebaai penghasil utama garam yaitu Sampang, Pamekasan dan Sumenep. Pertimbangan utama dalam penentuan lokasi kajian adalah fakta bahwa di wilayah Pulau Madura berkontribusi sekitar $60 \%$ dari luas lahan garam nasional yaitu dengan luas lahan produktif $12.326,73 \mathrm{Ha}$ dari potensi lahan seluas 16.421 Ha. Jenis data tentang faktor faktor penyebab ketidakberdayaan petani garam serta kondisi sosial, ekonomi dan budaya petani garam adalah data primer dan sekunder. Data primer diperoleh dari observasi, key informan yang terdiri atas tokoh pegaram rakyat, pemerintahan desa/ kecamatan, BPN (Badan Pertanahan Nasional) dan PT. Garam. Sementara untuk dara sekunder diperoleh dari Dinas Kelautan dan Perikanan, Dinas Perindustrian dan PT. Garam. Data diperoleh dengan metode observasi, indepth interview dan FGD (Focus Group Discussion).

Metode analisis yang digunakan dalam studi menggunakan mixed analysisi, yaitu mengkombinasikan analisis deskriptif kuantitatif 
dan analisis kualitatif. Analisis kualitatif terdiri dari tiga alur kegiatan yang terjadi secara

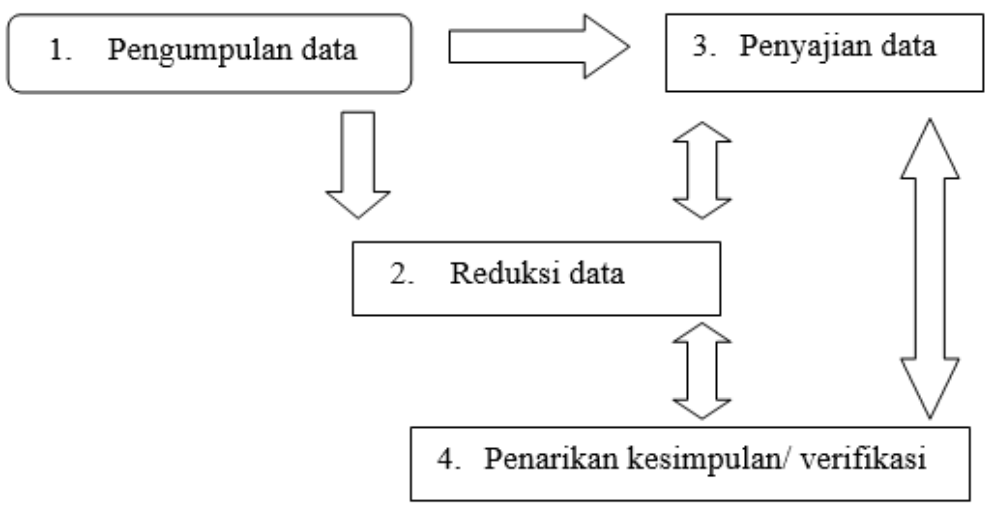

Gambar 2. Alur Analisis Kualitatif bersamaan antara reduksi data, penyajian data dan penarikan kesimpulan.
Secara teknis prosedur atau mekanisme
is kualitatif yang dilakukan dalam studi analisis kualitatif yang dilakukan dalam studi terdiri dari tiga kegiatan yaitu :

\section{Reduksi data}

Data yang diperoleh di lapang disusun rapi, terinci dan sistematis. Setiap selesai mengumpulkan data, data tersebut perlu direduksi yaitu dengan memilih hal-hal pokok yang sesuai dengan pokok penelitian. Data yang telah direduksi memberikan gambaran yang lebih tajam tentang hasil penelitian.

2. Display data

Data yang semakin banyak, kurang memberikan gambaran yang menyeluruh. Dalam penelitian deskriptif, data kuantitatif juga diperlukan untuk mendukung data kualitatif. Oleh karena itu diperlukan penyajian data yang menyajikan data dalam bentuk peta, bagan, tabel, grafik atau deskripsi.

3. Pengambilan kesimpulan atau verifikasi

Dari data yang didapat, peneliti mencoba mengambil kesimpulan. Verifikasi) dilakukan dengan maksud menggali data ulang yang pernah dikumpulkan atau mencari data lain untuk mengecek tentang kebenaran fenomena tertentu.

Pengambilan kesimpulan dalam kajian yang berupa perumusan strategi pemberdayaan petani garam melalui pendayagunaan aset pertanahan dilakukan secara bersama-sama antara peneliti dengan para informan melalui
FGD dan particpatory resource mapping. Hal ini juga didasarkan pada kondisi data ketidakberdayaan petani garam dan kondisi sub sistem budaya - kelembagaan dan sub sistem ekonomi petani garam.

\section{HASIL DAN PEMBAHASAN}

\section{Kondisi Subsistem Budaya - Kelembagaan Petani Garam.}

Garam dikaitkan dengan kehidupan masyarakat Madura dalam subsistem budaya adalah suatu hal yang tidak terpisahkan. De Jong (2011) menyatakan bahwa bagi masyarakat Madura secara umum dan temurun telah melakukan usaha pegaraman sejak lama. Para petani di wilayah Kabupaten Sumenep dikenal sebagai cikal bakal pembuatan garam. Dikisahkan Syeh Anggasuta menemukan butiran kristal yang kemudian dibiarkan berminggu-minggu hingga akhirnya menjadi garam. Desa Pinggir Papas Kecamatan Kebun Dadap Kabupaten Sumenep dikenal ada acara ritual nyadar. Acara ini dilakukan untuk mengenal Syech Anggasuta yang menawali proses pembuatan garam. Diceritakan bahwa Syech Anggasuta adalah pahlawan yang menyelamatkan pelarian tentara Kerajaan Klungkung Bali yang kalah berperang melawan Keraton Sumenep. Para pelarian inilah yang menjadi cikal bakal penduduk Pinggir Papas. Hal ini serupa dengan temuan Sandu, et al (2010), dimana produksi garam di Rumania juga 
telah dilakukan berabad-abad secara turun temurun.

Petani garam biasanya menggarap tanah pegaramanya selama 5-6 bulan saja, yakni pada musim kemarau. Selama musim penghujan petani garam mengelola tanah pegaramannya untuk digunakan sebagai tambak bandeng dan udang. Namun demikian ada juga petani garam yang beralih pekerjaan sebagai buruh di kota. Bagi para mantong selama tidak memperoleh penghasilan, mereka meminjam uang dari pemilik tanah pegaraman atau pedagang garam dengan perjanjian ikatan yang disepakati. Kondisi seperti ini menjadikan para mantong terjebak pada ketergantungan dengan pemilik tanah.

Dalam konsep interaksi masyarakat dan akar budaya, bagi masyarakat Madura tanah adalah sebuah kehormatan yang memiliki nilai dan posisi yang saagat penting yang menyangkut harkat marbat individu dan kelompok sehingga dalam kasus tertentu konflik lahan dapat berujuang pada carok jika status dan eksistensi lahan atau tanah diganggu gugat olehpihak lain. Sehingga bagi masyarakat dengan adanya pengakuan penduduk sekitar dan surat keterangan pemilikan tanah yang dikeluarkan oleh desa (pepel) sudah dirasa cukup. Hambatan biaya dan keluhan sulitnya birokrasi pengurusan menjadikan alasan dominan petani garam. Sehingga perlu ada sosialisasi yang lebih gencar dalam pengurusan sertipikat ini. Selain itu hambatan yang cukup unik adalah adanya buku pepel yang biasanya ada di kepala desa seringkali mengalami kondisi "penyanderaan". Dimana bila kepala desa lama tidak terpilih lagi, maka buku pepel tanah dalam desa itu juga ikut dibawa. Jika ada warga yang akan melakukan pengurusan maka warga dikenakan biaya. Hal ini agak berbeda jika dibandingkan dengan petani garam di Sumenep. Para petani garam di Sumenep sudah banyak yang menyadari pentingnya sertipikasi tanah dan menjaminkannya ke bank untuk mendukung produksi garam.

Terdapat temuan unik di Desa Tanjung Kecamatan Pademawu Pamekasan, dimana di desa tersebut telah terlembaga budaya bergilir dalam usaha produksi garam dalam suatu keluarga. Tanah pegaraman yang diwariskan tidak dibagi-bagikan kepada tiap anak, tetapi digilir pengusahaannya oleh tiap-tiap saudara kandung per tahunnya, sehingga luas tanah pegaraman suatu keluarga tetap utuh tanpa terpecah-pecah dan terpencar (less fragmentation and division) yang berbeda dari sistem pewarisan tanah yang sangat umum diparktekkan di kawasan pertanian dan pedesaan Indonesia. Demikian juga di Desa Karanganyar Kecamatan Kalianget Sumenep petani garam ada yang telah menerapkan konsep corporate farming dalam melakukan usaha pegaraman.

Kajian kelembagaan/ aturan-aturan yang ada dalam usaha pegaraman dapat dimulai dari aspek produksi garam. Berdasarkan kepemilikan tanah maka usaha produksi garam dapat dibagi menjadi (1) Usaha pegaraman yang digarap oleh pemilik tanah sendiri; dan (2) usaha pegaraman yang dilakukan oleh petani penggarap (mantong). Jika usaha pegaraman dilakukan oleh pemilik tanah maka semua kegiatan mulai dari penyediaan peralatan produksi, persiapan produksi, proses produksi, pemungutan hingga pemasaran garam menjadi tanggung jawab dalam otonomi pemilik tanah tersebut. Namun jika usaha produksi garam ini dilakukan oleh mantong, maka pemilik tanah akan menyediakan input produksi dan peralatan yang diperlukan dalam produksi garam. Demikian juga pemilik tanah akan memainkan peranannya dalam pemasaran produk garam. Sementara mantong bertanggung jawab pada proses persiapan tanah pegaraman, perawatan tanah pegaraman selama produksi serta pemungutan. Adapun pembagian hasil yang berlaku adalah sepertiga hasil garam dibagi kepada mantong dan dua pertiga hasil dibagi kepada pemilik tanah. Ketika terjadi kerugian maka beban biaya peralatan yang telah dikeluarkan hanya akan dibebankan kepada pemilik tanah.

Berpindahnya mantong untuk mengerjakan pada pemilik tanah yang lain adalah sebuah kewajaran. Biasanya mantong akan memilih pemilik tanah yang ringan memberikan sarana produksi pendukung usaha pegaraman dan ringan memberikan bonus ketika 
memperoleh harga jual garam yang baik. Hal yang sama juga dapat dilakukan oleh pemilik tanah, dimana pemilik tanah dapat saja memutus hubungan dengan mantong apabila dirasa mantong tersebut memiliki produktivitas kerja yang rendah. Sebaliknya, jika pemilik tanah cocok dengan mantong tersebut maka pemilik tanah berupaya mengikatnya salah satunya dengan cara memberikan pinjaman uang selama belum panen. Apabila musim produksi garam telah usai atau memasuki musim hujan maka pengelolaan tanah pegaraman sepenuhnya akan diserahkan kepada pemilik tanah.

Pemegang peranan dalam pemasaran terkait dengan harga jual dan kemana garam akan dijual adalah pemilik tanah. Terdapat dua saluran pemasaran garam. Saluran pertama adalah petani garam $\rightarrow$ tengkulak $\rightarrow$ pedagang besar $\rightarrow$ pabrik. Sementara saluran kedua adalah petani garam $\rightarrow$ tengkulak $\rightarrow$ pabrik. Dijelaskan juga bahwa saluran pemasaran kedua lebih efisien dibandingkan dengan saluran pemasaran yang pertama. Sistem pasar garam yang oligopsonik menjadikan petani garam memiliki posisi tawar rendah dalam penentuan harga. Fauziyah dan Ihsannudin (2014) menjelaskan bahwa lemahnya posisi tawar petani ini disebabkan oleh kurangnya informasi yang dimiliki petani garam.

Pemasaran garam ini sebenarnya telah diatur dengan beberapa regulasi yang ada. Pemerintah melalui Peraturan Menteri Perdagangan Nomor 125/MDAG/PER/12/2015 berupaya mengatur ketentuan impor garam guna mengatur neraca supply-demand garam nasional. Beberapa poin penting penting dalam regulasi tersebut adalah Pertama, Garam yang dapat diimport adalah garam untuk konsumsi (Kadar $\mathrm{NaCl}$ paling sedikit 94,7\% hingga kurang dari 97\%) dan garam untuk industri (Kadar $\mathrm{NaCl}$ paling sedikit 97\%). Kedua, Impor garam industri dapat dilakukan oleh perusahaan yang melakukan kegiatan usaha di bidang industri yang menggunakan bahan baku atau bahan penolong garam industri dan dilarang untuk diperdagangkan dan dipindahtangankan. Ketiga, Garam untuk konsumsi dapat diimpor oleh BUMN yang bergerak di bidang pegaraman jika gagal panen raya dan yang berakibat stok garam konsumsi tidak dapat memenuhi kebutuhan dalam negeri dan/ atau ketersediaan garam konsumsi tidak dapat memenuhi kebutuhan dalam negeri. Keempat, Importir produsen garam iodisasi dapat mengimpor untuk memenuhi kebutuhan industrinya. Kelima, Importir produsen garam iodisasi dilarang mengimpor dalam masa satu bulan sebelum panen raya, selama panen raya dan dua bulan setelah panen raya. Keenam, Penetapan masa pelarangan impor garam disesuaikan dengan pencapaian produksi pada masa panen raya agar dapat memenuhi kebutuhan nasional. Hal ini ditentukan oleh menteri perdagangan dengan mempertimbangkan menteri perindustrian atau pejabat yang ditunjuk. Ketujuh, Impor garam untuk keperluan industri garam iodisasi dilarang apabila harga rata-rata garam curah diatas truk di titik titik pengumpul berada di bawah harga garam KP 1 dan KP 2 yang ditetapkan oleh Direktur Jenderal. Dimana harga garam Kp 1 dan harga garam KP 2 ditetapkan oleh Direktur Jenderal berdasarkan kesepakatan instansi / asosiasi terkait. Kedelapan, Penentuan jumlah garam yang diimpor dihitung berdasarkan kesepakatan antar instansi teknis / lembaga atau asosiasi terkait di bidang garam. Jumlah tersebut disesuaikan secara proporsional berdasarkan pembelian garam petani.

Pada saat ini harga garam yang berlaku masih mengikuti Peraturan Dirjen Perdagangan Luar Negeri Nomor 02/DAGLU/PER/ 5/ 2011. Dalam peraturan tersebut ditetapkan bahwa harga jual garam curah di atas truk di titik pengumpul untuk KP 1 adalah Rp. 750.000 per ton dan untuk KP 2 adalah 550.000 per ton. Garam dengan KP 1 adalah garam dengan dengan kadar $\mathrm{NaCl}$ minimal 94,7\%, berwarna putih bening dan bersih dan ukuran butiran garam minimal $4 \mathrm{~mm}$. Sedangkan garam dengan KP 2 adalah garam dengan kadar $\mathrm{NaCl} 85 \%$ sampai dengan $94,7 \%$ warna putih dan ukuran garam minimal $3 \mathrm{~mm}$. 


\section{Kondisi Subsistem Ekonomi Petani Garam}

Subsistem ekonomi ini akan dibahas dengan dua pendekatan yaitu pendekatan sumberdaya (faktor produksi) dan pendekatan teknologi (fungsi produksi). Pendekatan aspek faktor produksi dapat dijelaskan bahwa pembuatan garam di Madura dilakukan dengan memanfaatkan sinar matahari (solar evaporation) serta memerlukan lahan spesifik. Adi (2006) menyatakan bahwa lahan garam yang dibutuhkan adalah lahan dekat dengan laut, mempunyai porositas tanah rendah atau tanahnya tidak berpasir. Secara teknis yang berpengaruh terhadap produksi garam adalah mutu air laut, keadaan cuaca, porositas tanah, pengaturan aliran air, cara pungutan, dan air tua laut (bittern) (Purbani, 2008). Dalam memproduksi garam tanah pegaraman pegaraman dibagi menjadi tiga bagian yaitu waduk (bozem), peminihan dan meja kristalisasi. Petani garam madura umumnya menggunakan $20 \%$ luas tanah pegaraman untuk bozem, 50\% untuk peminihan dan $30 \%$ untuk meja kristalisasi.

Input atau faktor produksi dalam usaha pegaraman terdiri atas peralatan produksi, tenaga pengggarapan, tenaga pungut, tenaga pengarungan, tenaga pengangkutan dan lainlain. Penggunaan atas input atau faktor produksi tersebut akan menimbulkan biaya yang dinamakan dengan biaya produksi usaha pegaraman.

Tabel 1. Biaya Produksi Garam Per Ha Per Musim

\begin{tabular}{lcr}
\hline \multicolumn{1}{c}{ Jenis Biaya } & $\begin{array}{c}\text { Besar Biaya } \\
(\mathrm{Rp} / \mathrm{ha})\end{array}$ & $\begin{array}{c}\text { Persentase } \\
(\%)\end{array}$ \\
\hline Biaya Peralatan & 1.929 .161 & 11.77 \\
Garap & 6.613 .200 & 40.34 \\
Pungut & 1.058 .667 & 6.46 \\
Pengarungan & 2.307 .893 & 14.08 \\
Pengangkutan & 3.705 .333 & 22.60 \\
Biaya Lain-Lain & 780.712 & 4.76 \\
\hline Total & 16.394 .966 & 100 \\
\hline
\end{tabular}

Sebagian besar $(40,34 \%)$ biaya yang dikeluarkan adalah untuk tenaga kerja pada saat penggarapan persiapan sebelum panen dan pemeliharaan selama masa panen. Hal ini dikarenakan mahalnya biaya tenaga kerja yang digunakan untuk proses tersebut, yaitu $\mathrm{Rp}$ 45.000 hingga $\mathrm{Rp} 50.000$ per hari. Kegiatan tenaga kerja selanjutnya adalah pemungutan yang biasanya dipungut setiap 10 hari sekali.

Rata-rata produksi per hektar per musim sebesar 52,93 ton dengan harga rata-rata yang diterima adalah Rp. 484 per kg. Sehingga penerimaan petani garam tersebut adalah $\mathrm{Rp}$. 25.640.907. Setelah dikurangi dengan biaya ( $\mathrm{Rp}$ 16.394.966) maka diperoleh pendapatan petani garam sebesar $\mathrm{Rp}$ 9.245.941 per hektar per musim. Sehingga jika diproksikan dalam satu tahun maka pendapatan petani garam adalah sebesar 770.495 per hektar per bulan. Jika petani garam tersebut adalah mantong maka pendapatannya adalah sepertiga dari jumlah tersebut sehingga pendapatan mantong adalah Rp 231.148 per hektar per bulan. Nilai ini bisa saja akan menjadi lebih rendah jika harga garam juga kembali turun seperti pada pertengahan musim tahun 2012 ini, dimana harga garam bisa menyentuh harga $\mathrm{Rp} 250$ per $\mathrm{Kg}$. Sehingga dengan demikian paling tidak petani garam garam memerlukan minimal 2 hektar tanah pegaraman. Luasan ini nantinya petani garam tersebut akan memperoleh pendapatan sebesar Rp 1.540.990 per bulan.

Jenis usaha pegaraman ini masih memanfaatkan tenaga kerja dalam keluarga. Banyaknya anggota rumah tangga petani garam akan berpengaruh terhadap penyediaan tenaga kerja dalam usahatani dan sekaligus merupakan beban rumah tangga dalam penyediaan kebutuhan sehari-hari (Ihsannudin, 2010). Sebagian besar petani garam memiliki jumlah 
tanggungan keluarga 5 orang (64\%). Hal ini mengimplikasikan bahwa petani garam yang melakukan usaha pegaraman mempunyai lebih sedikit modal berupa tenaga kerja dalam keluarga yang dapat membantu melakukan aktivitas usaha pegaraman. Sebenarnya dengan adanya tambahan modal berupa tenaga kerja dalam keluarga ini maka petani garam dapat menekan biaya yang dikeluarkan dan pada akhirnya dapat meningkatkan pendapatan petani garam.

Teknologi yang digunakan oleh para petani garam dalam usaha pegaraman di Madura masih dalam kategori tradisional. Meski ada petani garam yang sudah mengaplikasikan teknologi geo membran namun jumlahnya masih sangat sedikit karena mahalnya pembelian geo membran. Teknologi geo membran adalah dengan memasang semacam terpal di meja kristalisasi garam untuk mempercepat proses penguapan. Rendahnya aplikasi teknologi juga diperparah dengan ketersediaan dan kualitas infrastruktur produksi dan infratsruktur transportasi-logistik yang rendah sehingga mengakibatkan meningkatkan biaya produksi. Sebagai contoh ada dua desa di Kabupaten Sampang, transportasi produk garam harus dilakukan dengan menggunakan perahu yang menyusuri muara sungai untuk bisa dibawa ke daratan sehingga memakan waktu yang panjang dan biaya yang mahal. Penggunaan transportasi perahu ini tentunya akan menambah beaya transport yang lebih mahal. Demikian pula ketersediaan tenaga kerja di bidang pegaraman juga sudah semakin menurun yang pada akhirnya menjadikan tingkat upah buruh tani atau pekerja penggaraman meningkat secara signifikan. Padahal sebagaimana hasil kajian Ariyani (2010) bahwa persentase terbesar biaya yang dikeluarkan dalam usaha pertanian termasuk pegaraman adalah komponen biaya tenaga kerja.

Faktor Faktor Penyebab Ketidakberdayaan Petani Garam

Permasalahan masyarakat pegaram ini terjadi mulai dari sektor hulu, on farm hingga ke sektor hilir. Pada sektor hulu masyarakat pegaram sudah dihadapkan pada ketiadaan lembaga keuangan yang bersedia membiayai produksi garam sebagai unit usaha produksi produktif. Selama ini asset tanah pegaraman dinilai dengan melihat nilai jual obyek pajak (NJOP) yang berlaku dan tidak dipandang sebagai asset ekonomi produktif. Sementara sektor penunjang lain seperti kelompok petani garam yang ada belum mampu memberikan nilai tawar yang signifikan bagi keberpihakan petani garam. Sebagian besar kelompok petani garam yang ada saat ini terbentuk bersifat top down karena adanya program bantuan Pemberdayaan Usaha Garam Rakyat (Pugar) dari Kementerian Kelautan dan Perikanan (KKP) yang dinamakan Kugar (Kelompok Usaha Garam rakyat). Keanggoataan Kugar ini terdiri dari petani pemilik lahan, matong dan juga penyewa. Jumlah kugar yang ada di Kabupaten Sampang adalah 219 Kugar, Pamekasan 123 Kugar dan Sumenep 142 Kugar. Sementara organisasi/ kelompok petani garam yang bersifat bottom up terdiri atas asosiasi-asosiasi tidak kurang ada 15 asosiasi petani garam yang ada di wilayah Sampang, Pamekasan dan Sumenep. Di Kecamatan Pengarengan Kabupaten Sampang terdapat satu koperasi garam yang bernama "Koperasi Al Amin". Meskipun bersifat bottom up, organiasasi petani garam ini cenderung bersifat menara gading. Organisasi diisi oleh kaum-kaum terdidik dan elit yang justru seringkali juga memainkan peran ganda yakni sebagai petani sekaligus pedagang. Sehingga seringkali kondisi ini menimbulkan konflik kepentingan. Orgaisasi dalam skala lebih besar juga sudah terbentuk Komisi Garam Nasional yang berkedudukan di Pamekasan. Komisi garam ini berupaya untuk mengkoordinasikan banyaknya asosiasi-asosiasi yang secara mandiri muncul dan berupaya memperjuangkan kepentingan petani garam. Meski demikian sebagian besar petani garam masih belum mengenal keberadaan Komisi Garam nasional ini.

Pada sisi on farm, sebagaimana yang dimaklumi bahwasannya usaha pegaraman ini sangat tergantung pada musim dan kondisi tanah yang spesifik. Sehingga produksi garam 
maksimal hanya dapat dilakukan 5-6 bulan dan juga tidak semua garis pantai dapat dijadikan tanah pegaraman. Luas tanah pegaraman menjadi faktor penting dalam produksi garam. Kepemilikan dan penguasaan tanah pegaraman sangat bervariasi. Petani yang memiliki tanah pegaraman luas cenderung memperoleh pendapatan yang besar dan sangat timpang jika dibandingkan dengan petani dengan luas tanah pegaraman yang lebih kecil. Hal ini dikarenakan optimalnya pembagian tanah pegaraman untuk difungsikan sebagai bozem, peminihan dan meja kristalisasi.

Pada waktu jeda garam tidak berproduksi, tanah pegaram digunakan untuk budidaya ikan dan udang namun kurang berproduksi dengan baik karena salinitas atau kadar garam dalam air yang tinggi. Sehingga tidak mengherankan justru banyak petani garam yang berpindah profesi pada saat memasuki musim hujan. Penggunaan faktor produksi yang masih tradisional menjadikan produktivitas garam menjadi rendah. Sementara untuk mengintroduksi teknologi seperti geo membaran petani garam masih terkendala modal.

Permasalahan yang dihadapi petani garam tidak berhenti pada tingkatan on farm. Setelah garam diangkat dari tanah pegaraman permasalahan harga menjadi permasalahan krusial yang dihadapi petani. Keberadaan garam impor, kualitas garam yang rendah, lemahnya posisi tawar petani dalam informasi harga serta dalam penentuan kualitas menjadikan harga garam petani dihargai rendah rendah. Meskipun sudah ada regulasi harga untuk garam KP 1 dan KP 2 namun harga ketentuan tersebut tidak sampai dirasakan di tingkat petani.

Keberadaan petani penggarap atau mantong tidak dapat disepelekan mengingat keberadaannya menghuni sekitar $80 \%$ dari jumlah petani garam yang ada. Hubungan patron - client semakin memperburuk posisi tawar mantong. Selama ini mantong mendapatkan bagian sepertiga dari hasil jika biaya input berasal dari patron. Sementara mantong akan mendapatkan separo hasil jika mantong turut berperan dalam memberikan biaya input. Kondisi semacam ini tidak hanya terjadi pada pegaraman di Madura saja, namun juga terjadi di daerah pegaraman di pantai utara Jawa. Sebagaimana yang diungkapkan Rochwulaningsih (2007) bahwa problem mendasar yang dihadapi petani garam, yaitu beroperasinya sistem kapitalisme yang mengantarkan mereka pada kondisi yang termarjinalkan.

\section{Strategi Pemberdayaan Ekonomi Petani Garam Melalui Pendayagunaan Aset Pertanahan}

Ketidakberdayaan petani garam tersebut dapat dilakukan introduksi pemberdayaan dari aspek pertanahan. Tanah dalam usaha produksi garam memegang peranan yang signifikan (Ihsannudin, 2012b). Berdasarkan dari tipe petani garam maka strategi pemberdayaan ini ditujukan kepada petani garam pemilik tanah dan mantong dengan pendekatan yang berbeda.

Pemberdayaan kepada petani pemilik tanah pegaraman dapat dilakukan langsung pada upaya legalisasi asset/ sertipikasi tanah pegaraman yang dimiliki. Peran pemerintah melalui Badan Pertanahan Nasional dapat melakukan program sertipikasi tanah (Prona). Berdasar hasil kajian ini maka tanah pegaraman yang diprioritaskan untuk mendapatkan program adalah tanah pegaraman yang memiliki beberapa kriteria. Kriteria pertama adalah tanah bebas sengketa, konflik maupun berperkara. Mengacu pada Peraturan Kepala BPN Nomor 3 Tahun 2011 dinyatakan bahwa yang dinamakan sengketa adalah perselisihan pertanahan antara orang perseorangan, badan hukum, atau lembaga yang tidak berdampak luas secara sosio-politis. Konflik adalah perselisihan pertanahan antara orang perseorangan, kelompok, golongan, organisasi,badan hukum, atau lembaga yang mempunyai kecenderungan atau sudah berdampak luas secara sosio-politis. Sedangkan perkara adalah perselisihan pertanahan yang penyelesaiannya dilaksanakan oleh lembaga peradilan atau putusan lembaga peradilan yang masih dimintakan penanganan perselisihannya di Badan Pertanahan Nasional Republik Indonesia. Kriteria kedua adalah tanah pegaraman dengan luas maksimal 2 ha. Hasil 
perhitungan usaha pegaraman menunjukkan bahwa petani dengan luas tanah maksimal 2 ha masih masuk dalam kategori miskin yang patut diberdayakan. Kriteria ketiga adalah terdapat kelompok petani garam yang kuat. Program pemberdayaan akan menjadi efektif dan efisien bila berbasis kelompok dan bukan perseorangan. Krtiteria keempat adalah ditujukan pada para petani garam yang memiliki budaya dan kelembagaan yang kuat dan kondusif. Hal ini penting untuk dapat menjamin bahwa program yang dilakukan akan berjalan dengan baik.

Pemahaman petani garam yang masih rendah akan pentingnya sertipikasi serta prosedur sertipikasi memerlukan sosialiasi yang tepat dan komprehensif dari lembaga terkait (BPN). Sehingga ketika pemahaman ini telah terbangun maka upaya sertipikasi tanah pegaraman dapat terwujud.

Sementara program pemberdayaan petani garam berbasis pertanahan bagi para mantong adalah dengan melakukan redistribusi Tanah Obyek Landreform (TOL). Sesuai dengan Peraturan Pemerintah Nomor 224 Tahun 1961 Tentang Pembagian Tanah dan Pemberian Ganti Kerugian, disebutkan bahwa pelaksanaan Landreform akan dibagikan menurut ketentuanketentuan diantaranya: Pertama, tanah-tanah selebihnya dari batas maksimum sebagai dimaksudkan dalam Undang-Undang Nomor 56 Tahun 1960 dan tanah-tanah yang jatuh pada Negara, karena pemiliknya melanggar ketentuan-ketentuan Undang-undang tersebut. Kedua, tanah-tanah yang diambil oleh pemerintah, karena pemiliknya bertempat tinggal diluar daerah, sebagai yang dimaksudkan dalam Pasal 3 ayat 5. Ketiga, tanah-tanah Swapraja dan bekas Swapraja yang telah beralih kepada Negara, sebagai yang dimaksudkan dalam Diktum Keempat huruf A Undangundang Pokok Agraria, Keempat, tanah-tanah lain yang dikuasai langsung oleh Negara, yang akan ditegaskan lebih lanjut oleh Menteri Agraria.

Mengacu pada ketentuan tersebut, obyek tanah yang memungkinkan di redistribusikan adalah tanah tanah PT Garam yang saat ini disewakan/ dibagi hasilkan kepada petani garam seluas sekitar 343,6 Ha. Sementara untuk pembagian tanah dan syarat-syarat penerima redistribusi TOL mengacu pada Bab III Peraturan Pemerintah Nomor 224 Tahun 1961 Tentang Pembagian Tanah dan Pemberian Ganti Kerugian. Meski demikian hal ini perlu dilakukan dengan cermat agar tidak menimbulkan konflik baru dalam implementasinya. Jika redistribusi sudah terlaksana, dilanjutkan dengan legalisasi asset/ sertipikasi sesuai empat kriteria legalisasi asset/ sertipikasi tanah pegaraman sebagaimana telah disebut.

Upaya pemberdayaan petani garam jangan hanya sebatas pada legalisasi asset tanah pegaraman saja namun juga perlu pada akses tanah pegaraman. Hal ini ini dimaksudkan agar sertipikat yang telah dikapitalisasi jangan sampai berpindah tangan karena ketidakberdayaan petani garam dalam mengembalikan pinjaman atau justru dijual akibat meningkatnya nilai jual tanah karena telah tersertipikasi. Selanjutnya perlu ada sosialisasi dan pendampingan bagi para petani garam yang telah memperoleh sertipikat untuk dapat memperoleh akses menjadikan sertipikat tersebut menjadi active capital dari lembaga penjamin (bank atau koperasi) guna mendukung permodalan usaha pegaraman baik pada usaha primer pegaraman maupun pada usaha sekunder pegaraman. Menurut Istikomah (2013), terdapat beberapa faktor yang mempengaruhi seorang pemilik setipikat tanah memanfaatkannya sebagai agunan yaitu keinginan pengembangan usaha, kesesuaian jumlah kredit, prosedur peminjman dan kemampuan untuk membayar.

Hal yang tak kalah penting setelah tanah pegaraman dilakukan sertipikasi adalah perlunya konsolidasi tanah pegaraman. Sebagaimana yang tercantum pada peraturan badan pertanahan Nasional Nomor 4 tahun 1994 yang dinamakan dengan konsolidasi tanah adalah kebijakan pertanahan mengenai penataan kembali penguasaan dan penggunaan tanah serta usaha pengadaan tanah untuk kepentingan pembangunan, untuk meningkatkan kualitas lingkungan dan pemeliharaan sumber daya alam denga 
melibatkan partisipasi aktif masyarakat. Hal ini menjadi demikian penting mengingat usaha pegaraman ini memerlukan luasan bozem (waduk penampungan air), peminihan dan meja kritalisasi yang harus seimbang. Disebutkan bahwa luasan tanah pegaraman optimal adalah $20 \%$ digunaan sebagai bozem, $50 \%$ digunakan untuk peminihan dan $30 \%$ digunakan untuk meja kristalisasi. Pada petani garam dengan luas tanah pegaraman yang sempit dapat saja melakukan konsolidasi tanah dengan menggunakan bozem ataupun area peminihan secara bersama-sama. Hal penting lain dari upaya konsolidasi tanah ini adalah menghindari unsur pengotor pada air bahan baku pembuatan garam. Keberadaan pemukiman yang dekat dengan area tanah pegaraman dikuatirkan akan memberikan dampak limbah yang berakibat pada berkurangnya kualitas air laut sebagai bahan baku usaha pembuatan garam. Sebagaimana yang diungkapkan Keikha dan Keikha (2012), bahwasannya upaya konsolidasi tanah akan dapat menambah luasan, meningkatkan nilai tanah, mengurangi konsumsi air, efisiensi penggunaan mesin, meningkatkan produksi pertanian yang pada akhirnya akan mampu memberikan peningkatan pendapatan secara signifikan. Demikian pula dengan konsolidasi tanah ini maka area pegaraman akan lebih tertata sehingga memungkinkan mendekatkan collecting point pada tiap meja kristalisasi petani garam. Collecting point sebagaimana yang tertuang dalam SK Dirjen Daglu Nomor 02/Daglu/PER/5/2011 adalah tempat pengumpulan garam di tepi jalan yang dapat dijangkau oleh truck dan sejenisnya. Saat ini petani yang letak meja kristalisasinya jauh dari collecting point masih menggunakan ojek sepeda atau bahkan di Kabupaten Sampang masih menggunakan perahu. Kondisi ini akan menjadikan petani garam akan efisien dalam mengeluarkan biaya transportasi dan dapat mengurangi risiko biaya yang nantinya dapat berimbas pada risiko pendapatan (Ihsannudin, 2012a).

Usaha primer pada sisi on-farm pegaraman dimaksudkan untuk meningkatkan kuantitas dan kualitas produksi garam melalui introduksi teknologi baik secara fisis, chemis maupun biologi. Hal yang sedang dilakukan PT Garam dan beberapa petani di Sumenep adalah dengan penggunaan geo membrane yang mampu meningkatkan produktivitas garam sebesar $30 \%$. Upaya peningkatan produksi garam secara nasional melibatkan berbagai kementerian yang terkait dengan koordinasi Kementerian Perekonomian melalui SK Menko Perekonomian KEP-11/M.EKON/03/2011 dimana Indonesia bertekad mencapai berswasembada garam. Sehingga pihak yang perlu dilibatkan dalam kegiatan ini adalah Kementerian Kelautan dan Perikanan (KKP) sebagai leading sector dalam usaha pegaraman yang didukung BPN. Sementara pada sisi off farm dimaksudkan untuk meningkatkan added value garam seperti membangun gudang penyimpanan maupun mesin pencuci garam. Kegiatan ini tidak dapat dilakukan secara parsial namun dilakukan secara sinergis antara sektor yang berkepentingan seperti pihak Kementerian Perindustian yang didukung oleh BPN.

Selama musim hujan petani garam tidak dapat memproduksi garam sehingga diperlukan alternatif pendapatan yang dapat menopang kehidupan petani garam secara berkelanjutan. Sebagaimana yang diungkapkan Tridakusumah, dkk ( 2015) bahwa keterbatasan alam bagi petani garam seperti karena adanya musim hujan ini perlu melakukan berbagai strategi untuk dapat bertahan hidup. Lebih lanjut Carner (1984) menyatakan bahwa beberapa strategi yang dapat dilakukan oleh rumah tangga miskin pedesaan antara lain melakukan ragam pekerjaan meskipun dengan upah yang rendah, memanfaatkan ikatan kekerabatan serta pertukaran timbal balik dalam pemberian rasa aman dan perlindungan dan melakukan migrasi ke daerah lain sebagai alternatif terakhir apabila sudah tidak terdapat lagi pilihan sumber nafkah di desanya.

Berdasarkan beberapa strategi tersebut yang perlu diupayakan adalah bagaimana petani garam tetap berusaha di lahan pegaraman. Usaha sekunder pegaraman dimaksudkan untuk keberlanjutan pendapatan petani garam selama 
musim hujan dengan tetap berusaha di tanah pegaraman. Beberapa alternatif usaha tersebut seperti budidaya udang dan bandeng yang memiliki nilai ekonomi bagi petani garam. Hal ini penting mengingat selama musim hujan petani garam belum maksimal secara ekonomi dalam memanfaatkan tanah pegaraman.

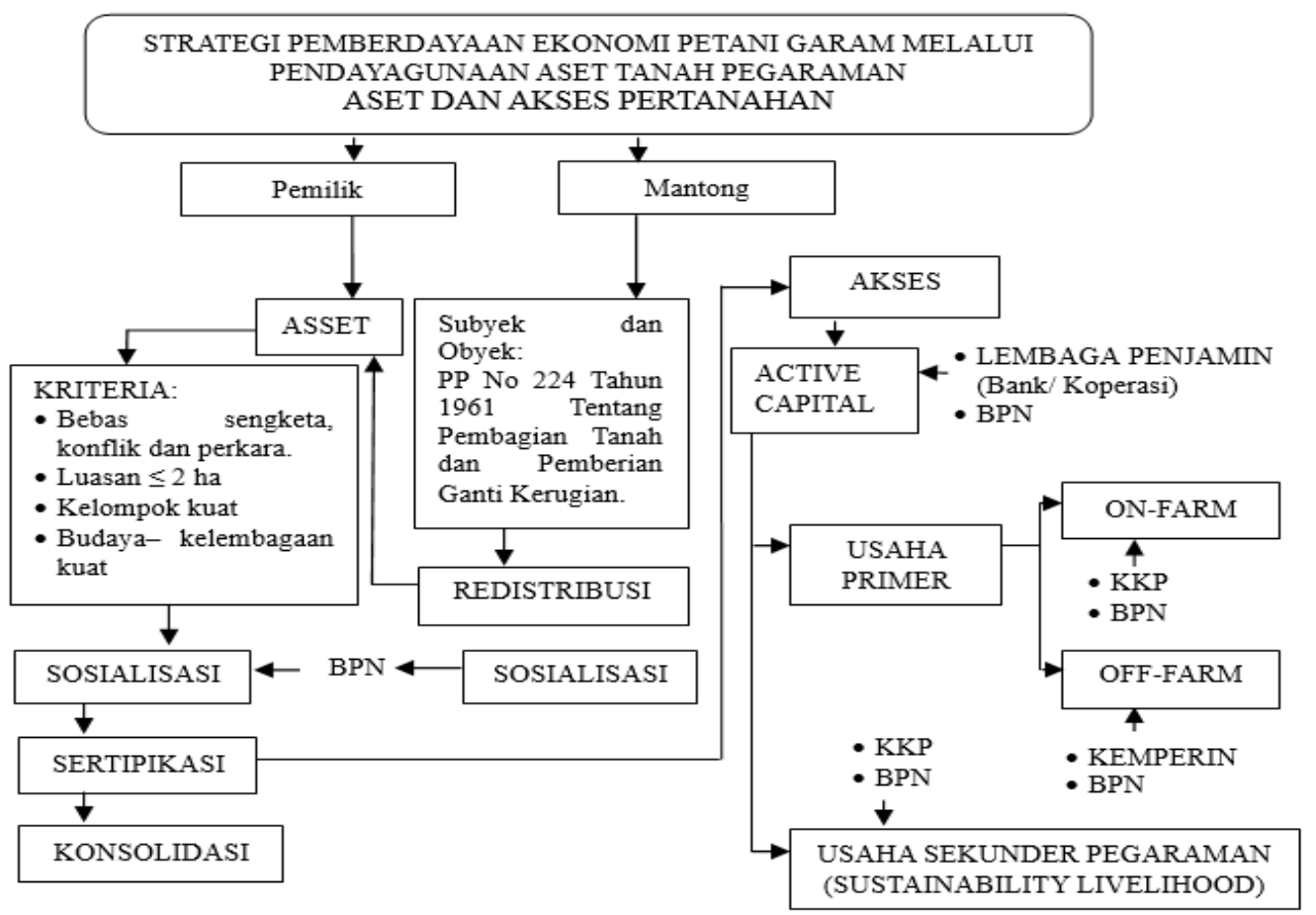

Gambar 3. Bagan Strategi Pemberdayaan Ekonomi Petani Garam

Meski menggunakan program dalam bidang pertanahan namun tetap perlu iklim partisipatif dari petani garam. Hal ini sangat penting mengingat partisipatif dari peserta pemberdayaan adalah kunci keberhasilan dari berbagai proyek pemberdayaan (Xu, et al. 2010). Sehingga petani dengan prinsip partisipasi ini petani tidak hanya dijadikan sebagai obeyek pemberdayaan namun juga sebagai subyek pemberdayaan.

\section{SIMPULAN}

Kajian subsistem budaya-kelembagaan mengungkapkan bahwa usaha pegaraman bagi masyarakat madura adalah merupakan hal yang terpisahkan dalam budaya Madura sejak lama. Dalam usaha pegaraman terdapat dua pelaku yaitu petani garam pemilik tanah dan petani garam penggarap (mantong) dengan pembagian hasil sepertiga dari hasil untuk petani penggarap. Sedangkan pada aspek pemasaran produk garam telah dilakukan pengaturan legal sampai penentuan harga dengan resmi namun masih belum dapat berjalan sesui ketentuan. Subsistem ekonomi dapat menjelaskan bahwa faktor produksi pembuatan garam sangat tergantung dari iklim dan cuaca dimana ketersediaan matahari dan tipologi serta kontur tanah pegaraman akan sangat berpengaruh pada produksi garam. Sementara itu teknologi yang dilakukan untuk memproduksi garam masih terbilang tradisional.

Faktor-faktor penyebab ketidakberdayaan petani garam terjadi mulai dari sektor hulu, on farm hingga sektor hilir. Sulitnya memperoleh modal usaha, organisasi kelompok yang belum tertata, musim yang tidak menentu menjadikan usaha produksi garam menjadi tidak maksimal. Sementara pada aspek pemasaran terlihat posisi tawar petani garam sangat lemah dalam penentuan kualitas dan harga garam, sehingga hal ini akan berimbas pada pendapatan yang diperoleh oleh petani garam. 
Strategi pemberdayaan ekonomi petani garam melalui pendayagunaan aset tanah pegaraman ditujukan kepada petani pemilik tanah dan mantong. Bagi petani pemilik tanah diarahkan untuk program sertifikasi tanah dengan kriteria tanah bebas sengketa, konflik dan perkara; luas maksimal 2 ha, masyarakat dengan kelompok yang kuat serta kondisi budaya kelembagaan yang baik. Setelah tanah tersebut tersertipikasi maka dilakukan pendampingan untuk dapat mengakses permodalan dengan menggunakan agunan sertipikat tanah tersebut kepada lembaga penjamin seperti koperasi atau bank. Tambahan modal tersebut diharapkan dapat digunakan untuk meningkatkan usaha primer yakni meningkatkan kuantitas dan kualitas produksi baik pada on farm maupun off farm. Sedangkan pemberdayaan bagi mantong diawali dengan kebijakan redistribusi tanah obyek land reform (TOL) yang nantinya juga akan diarahkan pada pensertipikatan dan selanjutnya mengikuti alur sebagaimana petani pemilik tanah. Tanah yang telah tersertipakt tersebut selanjutnya dapat dilakukan konsolidasi tanah yang berguna untuk meningkatkan kuantitas dan kualitas produksi garam yang nantinya berpengaruh pada peningkatan pendapatan. Tambahan modal tersebut juga dapat dipergunakan pada usaha sekunder di tanah pegaraman selama musim hujan seperti membudiayakan udang dan bandeng. Hal penting dalam meningkatkan kuantitas dan kualitas produksi garam adalah juga perlu dilakuakn konsolidasi tanah pegaraman.

\section{DAFTAR PUSTAKA}

Adi, Tukul Rameyo. 2006. Buku Panduan Pengembangan Usaha Terpadu Garam Dan Artemia. Pusat Riset Wilayah Laut dan Sumberdaya Nonhayati Badan Riset Kelautan dan Perikanan Departemen Kelautan dan Perikanan. Jakarta

Antonites, Alexander. 2016. The organization of salt production in early first millennium CE South Africa. Journal of Anthropological Archaeology, 44, pp.31-42

Ariyani, Aminah H.M. 2010. Variabilitas Pendapatan Rumah Tangga Petani di Kabupaten
Bangkalan (Studi Kasus di Kecamatan Klampis Kabupaten Bangkalan). Jurnal Embrio Volume 8 No. 2 April 2010

Byamugisha, FFK. 1999. The Effect of Land registration on Financial Development Economic Growth: A Theoritical and Aconceptual Framework. World Bank Policy Research Working Paper.

Conghe Song, Brian L White, Benjamin W Heumann. (2011). Hyperspectral Remote sensing of salinity stress on red (Rhizophora mangle) and white (Laguncularia racemosa) mangroves on Galapagos Islands. Remote Sensing Letters. Abingdon: Sep 2011. Vol. 2, Iss. 3; pg. 221

De Jonge, Huub. (2011). Garam, Kekerasan dan Aduan Sapi. Yogyakarta: Lkis

De Soto, Hernando. (2006). Rahasia Kejayaan Kapitalisme Barat. Jakarta: Qalam.

Deininger, Klaus and Feder Gershon. 2009. Land Registration, Governance, and Development: Evidence and Implications for Policy. The World Bank Research Observer, vol. 24, no. 2 (August 2009)

Djamhuri, Tri Lestari. (2008). Community Participation in a Social Forestry Program in Central Java, Indonesia: the Effect of Incentive Structure and Social Capital. Agro Syst (2008) 74:83-96

El Shaer, Hassan M. and A.J. Al Dakheel. 2016. Sustainable Diversity of Salt-Tolerant Fodder Crop-Livestock Production System Through Utilization of Saline Natural Resources: Egypt Case Study. Halophytes for Food Security in Dry Lands. pp.177-195.

Fauziyah dan Ihsannudin. 2014. Pengembangan Kelembagaan Garam Rakyat (Studi Kasus di Desa Lembung Kecamatan Galis Kabupaten Pamekasan. Jurnal Sosial Ekonomi Pertanian Vol 7(1): 52-59

Hayami, Yudiro and Godo, Yoshihisa. 2005. Development Economic from The Poverty To The Wealth of Nation. Oxford University Press. New York.

Hikmat, Harry. (2010). Strategi Pemberdayaan Masyarakat. Bandung : Humaniora Utama Press

Ihsannudin. (2010). Perilaku Petani Terhadap Risiko Usahatani Tembakau di Kabupaten Magelang. Embryo 7 (1) Juni 2010

Ihsannudin. (2011). Pengelolaan Sumberdaya Lahan Guna Pencapaian Swasembada Garam Nasional. Prosiding. Seminar Nasional 
Reformasi Pertanian Terintegrasi Menuju Kedaulatan Pangan. Fakultas Pertanian Universitas Trunojoyo 20 Oktober 2011 Hotel Sahid. Surabaya

Ihsannudin. (2012a). Tingkat Risiko Usaha Pegaraman Rakyat Masa Produksi 2011: Suatu Telaah Dalam Upaya Mengurangi Ketergantungan Impor. Prosiding. Seminar Nasional Revitalisasi Pertanian Berkelanjutan Menuju Ketahanan dan Kedaulatan Pangan. Universitas Muhammadiyah Jember, 17 Maret 2012

Ihsannudin, (2012b). Pemberdayaan Petani Penggarap Garam Melalui Kebijakan Berbasis Pertanahan. Jurnal. Activita 2 (1), 13-22

Ihsannudin. Hidayati, Ratna, Dwi. Sumada, Bertus and Pinuji, Sukmo. 2015. The Role Of Social Capital On Salt Smallholder Society Of Madura Indonesia In Land Certification Ownership. Scientific Journal of PPI - UKM Vol. 2 No. 42015

Istikomah. 2013. Pengaruh Program Sertifikasi tanah Terhadap Akses Permodalan Bagi Usaha Mikro dan Kecil: Studi Kasus Program Sertipikasi Tahun 2008 di Kabupaten Kulon Progo. Kawistara Vol. 3 No. 1 April 2013

Keikha, Zahra and Keikha, Alireza. 2012. Land Consolidation And Its Economic Effects On The City District Of Loutak Zabol. Int. J. Eco. Res Vol. 3 no. 5. 53-60

Purbani, Dini. 2009. Proses Pembentukan Kristalisasi Garam. Pusat Riset Wilayah Laut dan Sumberdaya Nonhayati Badan Riset Kelautan dan Perikanan Departemen Kelautan dan Perikanan. Jakarta

Rochwulaningsih, Yety. (2007). Petani Garam dalam Jeratan Kapitalisme: Analisis Kasus Petani Garam di Rembang Jawa Tengah. Jurnal Masyarakat Kebudayaan. Tahun XX No. 3 Juli 2007

Scott, james. 1998. Perlawanan Kaum Tani. Yayasan Obor. Jakarta

Segal, Richard D. Waite, Anya M. dan Hamilton, David P. (2009). Nutrient limitation of phytoplankton in Solar Salt Ponds in Shark Bay, Western Australia. Hydrobiologia (2009) 626:97-109
Sandu, Ion. Poruciuc, Adrian. Alexianu, Marius. Curca, Roxana-Gabriela and Weller, Oliver. 2010. Salt and Human Health: Science, Archeology, Anxient Text and Traditional Practices of Eastern Romania. The Mankind Quarterly 50(3): 225-256.

Susanto, Heru, et al. 2015. Development of Traditional Salt Production Process for Improving Product Quantity and Quality in Jepara District, Central Java, Indonesia. Procedia Environmental Sciences, 23, pp.175-178

Syafi'i, Ahmad, (2006), Potret Pemberdayaan Petani Garam, Implementasi Konsep dan Strategi. Surabaya: Untag Press

Todaro, Michael P and Smith, Stephen C. 2012. Economic Development. Adisson Wessley. Boston

Tridakusumah, Achmad, Choibar. Elfina, Mira. Mardiyaningsih, Dyah, Ita. Pioke, Jepri dan Bumulo, Sahrain. 2015. Pola Adaptasi Ekologi dan Strategi Nafkah Rumahtangga di Desa Pangumbahan. Solidality 3(3): 85-90

Widodo, Slamet. (2011). Strategi Nafkah Berkelanjutan Bagi Rumah Tangga Miskin di Daerah Pesisir. Makara Seri Sosial Humaniora 15(1), 10-21

Windari, Ratna, Artha. 2014. Keberpihakan Regulasi Pertanahan Terhadap Hak Masyarakat Adat (Studi Kasus Sengketa Tanah Adat Di Desa Kubutambahan, Kecamatan Kubutambahan, Kabupaten Buleleng). Jurnal Ilmu Sosial dan Humaniora Vol. 3 No. 1, April 2014

$\mathrm{Xu}$, Qingwen. Perkins, D Douglas and Chow, Julian Chun-Chun. (2010). Sense of Community and Social Capital as Predictor pf Local Political Participatian in China. Am $J$ Community Psychol (2010) 45: 259-27 